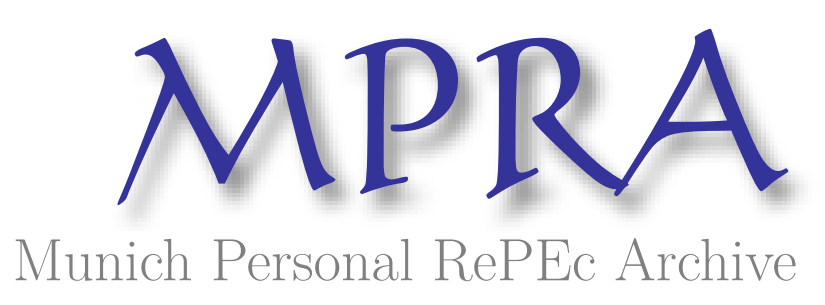

\title{
Does RD intensity influence leverage? Evidence from Indian firm-level data
}

Ghosh, Saibal

Reserve Bank of India

17 March 2012

Online at https://mpra.ub.uni-muenchen.de/38945/

MPRA Paper No. 38945, posted 22 May 2012 13:46 UTC 


\title{
Does R\&D intensity influence leverage? Evidence from Indian firm-level data
}

\author{
Saibal GHOSH ${ }^{1}$
}

\begin{abstract}
The paper examines the association between corporate leverage and their investment in R\&D. Towards this end, it develops certain testable propositions. These propositions are tested using a dataset of manufacturing firms in India covering the period 1995-2005. The estimates support the fact that firms which make high efforts on R\&D investments exhibit lower leverage ratios. Additionally, the estimates reveal that the dampening effect of R\&D-intensity on leverage is the highest for foreign private firms. For stateowned firms however, R\&D activity appears to be positively associated with leverage.
\end{abstract}

JEL Classification: E22, E44

Key words: R\&D intensity, leverage ratio, Tobit model, India

\section{Introduction}

The technological capacity of an economy is viewed as exerting an important influence on a country's international competitiveness and growth prospects. In view of its critical role, technology has received significant attention among researchers and policymakers (Cohen, 1995). A part of the innovative behavior consists of research and development, $R \& D$, in the firms. As the knowledge-based economy has become a paradigm for the new economy and as $R \& D$ has become a leading factor in national growth, firms have sought to enhance their competitiveness through R\&D investment.

Against this background, the analysis provides empirical evidence on the $R \& D$ efforts and financial structure from a panel of listed Indian companies over the period 1995-2005. Specifically, we address three issues: first, how the leverage ratio depends on $R \& D$ investment and other characteristics of innovative firms. Second, we analyze how R\&D intensity depends on internal capital as well as other firm-specific features. And third, how does the leverage ratio vary across different ownership categories of firms?

The remainder of the paper proceeds as follows. Section 2 provides an overview of the relevant literature. The empirical model is delineated in Section

\footnotetext{
1 The views expressed and the approach pursued in the paper are entirely personal.
} 
3 , followed by a discussion of the results in the subsequent section. The final section concludes.

\section{Related literature}

Extant theories of capital structure suggest certain reasons why firms with higher R\&D intensity might opt for particular sources of finance. According to the bankruptcy cost hypothesis, R\&D-intensive firms encounter problems in offering collateral to eventual debt lenders, and additionally, cannot attend a rigid payment scheme of their financial obligations, in view of the volatility of their $R \& D$ project returns. It is, therefore, not difficult to envisage a low debt equity ratio for these firms.

A common line of thinking of the existing literature is that the use of debt instruments is not a useful alternative to finance innovation, especially if the innovative firm is young and R\&D-specialized. This assertion is based on two facts. First, the rigidity imposed by debt contracts via fixed payments that are difficult to satisfy for non-diversified firms involved in $R \& D$ investments. Second, the intangibility and specificity of those assets linked to R\&D investments, a feature that diminishes their collateral value.

Another line of thinking, following from the pecking order hypothesis suggests that for innovative firms, there is likely to be a greater degree of asymmetric information between insiders and outsiders. As a consequence, these firms will find it difficult to make equity issues.

Another strand of the literature concentrates on the interface between firm ownership structure and $R \& D$ investments. Certain aspects relating to ownership structure, among other questions, are analyzed in the works by Love et al. (1996), Dixon and Seddighi (1996) and Francis and Smith (1995). More recently, using survey data for a sample of about 4000 firm-years of German firms for 1992-96, Czarnitzki and Kraft (2004) empirically examine the association between insider ownership and innovation, and in fact find a negative significant relationship.

In the Indian context, a growing body of literature has focused on various facets of R\&D activities. Focusing on R\&D efforts and technology imports, Kartak (1989) regressed R\&D efforts on technology imports with other explanatory variables, while others (Kumar, 1990; Kartak, 1991) adopted the 
converse approach. Subsequent evidence Kartak (1997) contended that there existed a two-way relationship between $R \& D$ efforts and technology imports, since on the one hand, technology imports influenced firms' in-house R\&D efforts, while on the other hand, the intensity of technology imports was, in itself, influenced by initial R\&D efforts. Exploiting this argument, using data on 48 industries for the period 1981-1990, Aggarwal (2000) found that while technology imports were weakly related with past R\&D efforts, whereas postliberalization, the impact of $R \& D$ efforts on technology imports increased significantly. More recent work (Kumar and Aggarwal, 2005) offers evidence to suggest that over the period of liberalization, increased competition has pushed local firms to rationalize their R\&D activity and make it more efficient. More importantly, the analysis indicates that $R \& D$ activities of local firms are primarily directed towards imbibing imported technology, whereas foreign firms essentially exploit the locational advantages to provide R\&D backup service for their parent companies. However, none of the studies in the Indian context focused explicitly on the interlinkage between R\&D efforts and firm leverage or for that matter, between R\&D and firm ownership and these aspects are central to the analysis of the paper.

\section{Database and empirical strategy}

\section{1 The database}

The source of the data is the Prowess database, generated and maintained by the Centre for Monitoring the Indian Economy (CMIE), a leading private think-tank in India. This database is being increasingly employed in the literature for firm-level analysis on Indian industry.

From the entire database, we have chosen all manufacturing companies listed on the National Stock Exchange over the period 1995-2005.2 The sample therefore includes firms whose main activity is in manufacturing, but excludes firms whose main activity is in the service sector, including finance. Screening for data consistency the final sample comprises of 665 firms.

Since the early 1990s, as part of reforms in the equity market, the CCI was abolished and corporate houses were provided the freedom to access

\footnotetext{
2 The National Stock Exchange, the state-of-the-art exchange for listed companies became operational from end 1994, which is why we focus on data from 1995 onwards.
} 
capital markets and price their securities, subject to prudential regulations of the Securities and Exchange Board of India (SEBI), the regulator of capital markets, whose functions are similar in scope with the Securities and Exchange Commission of the US. In the financial sector, the administered interest rate structure of banks was progressively rationalised since the mid-1990s. The prescriptions of rates on all term deposits, including conditions of premature withdrawal and offering uniform rate, irrespective of the size of deposits, was dispensed with. Likewise, lending rates were also deregulated. The removal of these restrictions not only meant a greater role of the price mechanism (interest rate) in the resource allocation process, but also provided an enabling mechanism for corporates to decide their capital structure, and with that, their levels of R\&D investment.

Table 1 sets out the definitions and summary statistics of all firm characteristics based on the sample of 665 manufacturing entities employed in the regression analysis. A common proxy for innovation is the ratio of the firm's R\&D expenditure to sales. Therefore, to differentiate firms based on their innovative activity, we construct a variable, High which equals 1 if this ratio equals to or exceeds the median value for all firms in a given industry and is zero, otherwise. In other words, High is a dummy variable which equals one if a firm is $R \& D$ intensive in the concerned industry. The remaining firms are classified as those with low R\&D intensity (Low). The descriptive statistics shows that, on average, the leverage ratio $(L E V)$ in $R \& D$ intensive firms are significantly lower than those in traditional sectors, and this difference is statistically significant. Likewise, short-term debt, defined as liabilities with a maturity of less than one year, is observed to be significantly lower in innovative firms. As regards the control variables, the table suggests that $R \& D$ intensive firms are typically larger in size and younger in age than their less innovative counterparts. Consistent with these observations, R\&D intensive firms are found to have lower asset tangibility.

We include one measure of non-bank external finance. Accordingly, we include a dummy for firms that belong to Indian business groups (Group), which comprise $65 \%$ of the sample firms. Given their access to cheaper intercompany loans, these firms might be better-placed to conduct $R \& D$ activities. 
Table 1 : Variable definitions and summary statistics

\begin{tabular}{|c|c|c|c|c|}
\hline Variable & Empirical definition & High $=1^{1,2}$ & $L o w=0^{1}$ & $\begin{array}{l}\text { Test } \\
\text { means } \\
\text { mea }\end{array}$ \\
\hline \multicolumn{5}{|c|}{ Firm characteristics } \\
\hline R\&D intensity & R\&D expenses/Sales & $0.011(0.057)$ & $0.0004(0.001)$ & $10.588(0.00)$ \\
\hline LEV & Total borrowings/Asset & $0.332(0.281)$ & $0.413(0.379)$ & $-10.009(0.00)$ \\
\hline STLEV & Short term borrowing/Asset & $0.113(0.103)$ & $0.138(0.157)$ & $-7.618(0.00)$ \\
\hline \multicolumn{5}{|l|}{ Controls } \\
\hline Size & $\log$ (total asset) & $2.539(0.618)$ & $2.223(0.586)$ & $21.353(0.00)$ \\
\hline Age & Log (number of years since firm incorporation) & $1.276(0.381)$ & $1.339(0.336)$ & $16.201(0.00)$ \\
\hline RoA & Operating profit/Asset & $0.037(0.595)$ & $0.024(0.203)$ & $1.186(0.23)$ \\
\hline Risk & Three-year rolling standard deviation of RoA & $0.043(0.451)$ & $0.046(0.132)$ & $-0.325(0.74)$ \\
\hline Tangible & Plant, property and equipment/total asset & $0.545(0.305)$ & $0.572(0.337)$ & $3.486(0.00)$ \\
\hline Profit margin & Operating profit/Sales & $0.087(0.219)$ & $0.059(0.176)$ & $2.295(0.00)$ \\
\hline INTFUNDS & $\begin{array}{l}\text { Log (cash flow), where cash flow is the aggregate of net profit and } \\
\text { depreciation in the previous period }\end{array}$ & $2.107(0.618)$ & $1.788(0.602)$ & $20.715(0.00)$ \\
\hline Growth & $\begin{array}{l}\text { Market value of equity (MVE)/(Book value of equity (BVE), where MVE } \\
\text { equals the closing price of share times the number of shares outstanding } \\
\text { and BVE equals equity capital plus reserves }\end{array}$ & $2.301(3.359)$ & $0.989(8.422)$ & $4.221(0.00)$ \\
\hline \multicolumn{5}{|c|}{ Ownership dummies } \\
\hline Group & Dummy $=1$, if a firm belongs to Indian business group, else zero & $0.676(0.468)$ & $0.610(0.488)$ & \\
\hline State & Dummy $=1$ if a firm is state-owned, else zero & $0.044(0.206)$ & $0.017(0.127)$ & \\
\hline Indian private & Dummy $=1$, if a firm is Indian private, else zero & $0.191(0.393)$ & $0.314(0.464)$ & \\
\hline Foreign & Dummy $=1$, if a firm is foreign-owned, else zero & $0.082(0.274)$ & $0.047(0.212)$ & \\
\hline Joint & Dummy $=1$, if a firm is jointly (state and Indian private) owned, else zero & $0.006(0.079)$ & $0.012(0.107)$ & \\
\hline
\end{tabular}

1 Means and (standard deviation); 2 High is a dummy variable which equals 1 if a firm is in the R\&D intensive sector

3 p-Values in parentheses; 4 We test the differences of means for non-dummy variables. Dummy variables do not satisfy the normality hypothesis to conduct a test of mean differences

The final set of variables focus on dummies that classify firm ownership. Accordingly, we distinguish between state-owned, foreign, Indian domestic private and joint corporates. Foreign firms may have access to cheaper financing via the parent firm and state-owned firms may secure financing by virtue of their implicit government guarantee. In the sample, $3 \%$ of the firms are state-owned, $7 \%$ are foreign, about $1 \%$ are jointly-owned; the remaining $25 \%$ are domestic private entities.

\section{2 Empirical Strategy}

For the empirical model, we employ a Tobit model with the R\&D intensity as the dependent variable. This takes into account the fact that many companies report zero values of $R \& D$ expenditure. The second model we estimate is a Tobit model restricted to firms with positive R\&D. This separation allows for greater flexibility. In particular, certain explanatory variables can have different effects between the two equations and hence, the process which results in investing in $R \& D$ is assumed not to be the same as that which 
determines the amount of the investment ( $R \& D$ intensity). Accordingly, we estimate the following reduced-form specification for firm $i$ at time $t$ as given by (1):

$R \& D_{i, t}=\delta_{0}+\delta_{1}[\text { Controls }]_{i, t}+O D_{t}+I D_{t}+\lambda_{t}+\eta_{i}+v_{i, t}$

where Controls is the set of control variables, including firm size, profit margin, internal funds, age of the firm and leverage. Following from our earlier discussion, since R\&D is expected to differ across firm ownership categories, we include dummies $(O D)$ classifying firm ownership. Industry dummies $(I D$, not reported) are included to control for industry-specific features not explicitly factored into the analysis. $\lambda_{\mathrm{t}}$ is a time-specific effect, $\eta_{\mathrm{i}}$ is the firm-specific effect and $v_{i, t}$ is a random error term, $v_{i, t} \sim \mathrm{N}\left(0, \sigma^{2}\right)$.

Firm size has generally been posited as a determinant of innovative activity. Nelson and Winter (1982) have justified a positive effect of firm size because larger firms are better able to appropriate returns from their innovative activity. We include, in addition to size, its squared term to account for possible non-linearities. Higher the profit margins, greater the availability of funds to the firm for undertaking $R \& D$ and hence, higher the resources allocated to R\&D. The age of the firm, measured as the number of years since its incorporation, captures firm experience and knowledge accumulation and proxies for efficiency differences (Erikson and Pakes, 1995). Finally, the internal funds in the period before to that of implementing the R\&D effort is included to control for the deep pocket policy.

None of the studies in the Indian context have examined the effect of firm leverage on its $R \& D$ activity. The literature suggests that capital structure has an influence on the R\&D activity of firms (Bah and Dumontier, 2001; Aghion et al., 2004). On the one hand, since $R \& D$ intensive firms encounter problems in offering collateral to eventual debt lenders, their leverage ratios are likely to be lower. On the other hand, innovative firms could encounter greater difficulties in making equity issues in view of the high degree of informational asymmetry between insiders and outsiders. Combining this argument with the fact that innovative firms have greater likelihood of generating investment opportunities suggests that their dependence on external finance would be higher. Therefore, innovative firms could be more reliant on debt finance. 
The aforesaid argument points to a possible endogeneity between leverage and R\&D. To address this concern, we apply a two-stage process. In the first stage, we regress leverage on the exogenous variables. This way, we obtain a value of leverage purged of its endogenous elements. To complete the two-stage process, we regress (1) after replacing leverage by its estimated value.

Accordingly, in the first stage, we estimate the following equations for leverage (and likewise, using short-term leverage as the dependent variable) as given by (2):

$$
\begin{gathered}
L E V_{i, t}=\delta_{1} \text { Size }_{i, t}+\delta_{2} \tan \text { gible }_{i, t}+\delta_{3} \text { growth }_{i, t}+\delta_{4} \text { RoA }_{i, t}+ \\
\delta_{5} \text { Risk }_{i, t}+O D_{t}+Y D_{t}+I D_{t}+\eta_{i}+v_{i, t}
\end{gathered}
$$

Specification (2) includes the following as explanatory variables: firm size (Size), asset tangibility (tangible), growth opportunities (growth), profitability $(R o A)$ and risk (risk). In their seminal paper, Harris and Raviv (1991) had observed that leverage increases with firm size, growth opportunities and tangibility and decreases with profitability and risk. This would suggest that expect $\delta_{1}, \delta_{2}, \delta_{3}>0, \delta_{4}$ and $\delta_{5}<0$.

\section{Results and discussion}

The first part of the analysis corresponds to the estimation of the auxiliary equation of leverage. The main message gleaned from table 2 can be summarised as follows. First, bigger firms exhibit high leverage, consistent with cross-country (Bah and Dumontier, 2001) and country-specific studies (Aghion et al., 2004). Second, firms with high growth opportunities exhibit lower leverage. This is supportive of the trade-off model which predicts that firms with greater investment have lower leverage because they have stronger incentives to avoid underinvestment. Profitability is negatively correlated with leverage, consistent with the notion that higher earnings should result in less leverage. Higher Risk is found to lower leverage. Finally, tangibility exhibits a positive relationship with leverage: firms with relatively few tangible assets tend to be more opaque and therefore, experience greater informational asymmetry problems. Costs of financial distress are higher in such firms; accordingly, R\&D activity in such firms tends to be lower. 
Table 2 : Determinants of firm leverage

\begin{tabular}{lr} 
Constant & $-0.340(0.024)^{* * *}$ \\
R\&D & $-0.393(0.002)^{* * *}$ \\
R\&D*Dummy Mature & \\
Controls & $0.819(0.005)^{* * *}$ \\
Size & $-0.007(0.003)^{* *}$ \\
Growth & $0.012(0.003)^{* * *}$ \\
Tangible & $-0.053(0.009)^{* * *}$ \\
RoA & $-0.001(0.0005)^{* * *}$ \\
Risk & \\
Ownership dummies & $0.531(0.010)^{* * *}$ \\
Group & $0.485(0.011)^{* * *}$ \\
State & $-0.122(0.009)^{* * *}$ \\
Indian private & $0.664(0.011)^{* * *}$ \\
Foreign & Included \\
Year dummies & Included \\
Industry dummies & 665,5051 \\
\hline No. of firms, Observations & $1995-2005$ \\
Time period & 0.981 \\
R-squared & 0.00 \\
Wald $x^{2}$ (p-Value) &
\end{tabular}

Coming to firm ownership, across all specifications, the coefficients on the foreign-owned and state dummies are positive and consistently significant, suggesting that these firm categories exhibit higher leverage. The coefficient on the variable group has an observed negative sign and is statistically significant at 0.01 level.

Table 3 : Determinants of R\&D intensity

\begin{tabular}{lrr}
\hline Dependent variable & $\mathrm{R} \& \mathrm{D} \geq 0$ & $\mathrm{R} \& \mathrm{D}>0$ \\
\hline Size & $(1)$ & $(2)$ \\
Size squared & $0.019(0.006)^{* * *}$ & $-0.010(0.005)^{* *}$ \\
Age & $-0.006(0.002)^{* * *}$ & $0.001(0.0007)$ \\
Age squared & $-0.012(0.005)^{* * *}$ & $0.0002(0.006)$ \\
Lag (Internal funds) & $0.007(0.003)^{* * *}$ & $0.0002(0.004)$ \\
Profit margin & $0.013(0.005)^{* * *}$ & $0.019(0.007)^{* * *}$ \\
LEV & $0.002(0.001)^{* *}$ & $0.014(0.007)^{* *}$ \\
Ownership dummies & $-\mathbf{0 . 0 2 4}(\mathbf{0 . 0 1 0})^{* * *}$ & $\mathbf{- 0 . 0 2 7}(\mathbf{0 . 0 0 9})^{* * *}$ \\
Group & & \\
State & $0.021(0.009)^{* * *}$ & $0.001(0.004)$ \\
Indian private & $0.011(0.008)$ & $0.016(0.009)$ \\
Foreign & $-0.004(0.009)$ & $-0.007(0.005)$ \\
Year dummies & $0.022(0.008)^{* * *}$ & $-0.007(0.003)^{* *}$ \\
Industry dummies & Included & Included \\
\hline No. of firms, Observations & Included & Included \\
Time period & 665,6272 & 437,3120 \\
McFadden R-squared & $1995-2005$ & $1995-2005$ \\
Wald $x^{2}$ (p-Value) & 0.202 & 0.197 \\
\hline Stald & $545.36(0.00)$ & $339.45(0.00)$ \\
\hline
\end{tabular}

Standard errors in parentheses

$* * *$ and ${ }^{* * *}$ indicates statistical significance at 1,5 and $10 \%$, respectively 
In Table 3, the coefficient on Size is positive and significant in (1), but negative in (2). Both these coefficients are statistically significant at 0.05 level or higher. In other words, large companies have a higher probability of pursuing $R \& D$, but with lower intensity. This is consistent with evidence that reports a positive effect of firm size on R\&D intensity (Bah and Dumontier, 2001; Aghion et al., 2004). More specifically, increases in firm size are likely to be associated with increase in R\&D up to a threshold. Beyond this threshold, R\&D declines with size. This concave quadratic relationship suggests that the marginal gains to $R \& D$ are initially bigger for large firms; subsequently, the cost of additional unit of $R \& D$ outweighs the benefits, leading to a scaling down of $R \& D$ expenses. Besides the statistical significance, the effect is also economically important. In particular, the magnitude on Size in (1) suggests that $R \& D$ on average, increases by $0.2 \%$ when Size rises by $10 \%$. The coefficient on Age is negative in both specifications, while that on Age squared is positive, indicating that the intensity of undertaking R\&D initially declines for older firms, but subsequently rises as firms realize the need to improve their products and processes in the face of competition, supportive of the evidence for India (Goldar and Renganathan, 1988). Profit margin bears a positive sign, conforming a priori expectations, although it is on the borderline of significance. The evidence is also in accordance with the deep pocket policy: lag INTFUNDS is found to exert a positive impact on the firm's R\&D efforts.

Central to the analysis is the sign and significance of the coefficient on leverage. The coefficient is found to be consistently negative and significant across both (1) and (2). This is consistent with evidence which views debt financing as inappropriate for funding $R \& D$ investments, given that servicing a debt typically require a stable stream of cash flows which can be deviated from in case of innovative projects. In terms of magnitudes, a $10 \%$ rise in leverage lowers R\&D by roughly 0.2 percentage points. In case STLEV (instead of LEV) is the dependent variable, the magnitude is slightly lower, but it retains its negative sign. This suggests that banks are not typically risk-averse in extending loans to innovative projects. What is however clear, is that debt holds a strategic disadvantage in the innovation market. 


\section{Concluding observations}

A growing body of research in the Indian context over the last few years has explored the technological capabilities of firms. Limited research has, however, been forthcoming as to how the R\&D intensity of firms' influences their capital structure or for that matter, whether this behaviour differs across firm ownership.

Using data on an extended sample of manufacturing firms, the evidence presented in the paper suggests that the behaviour of innovative firms, as captured by their R\&D intensity, differs from those of less innovative ones. More specifically, firms that use more debt exhibit significantly lower R\&D intensity. Exceptions to the fact are state-owned firms by virtue of their access to subsidized government loans. In addition, the findings indicate that the amount of firm's internal funds (implementation of a deep pocket policy) positively influences its $R \& D$ investment. Additionally, the dampening effect of leverage on $R \& D$ expenses is the highest for foreign firms.

The economic reforms initiated in 1992, seems to have provided an impetus to corporates to improve their R\&D activity. Notwithstanding this salutary development, $R \& D$ intensities of Indian companies are quite low compared to global standards. This suggests the need for the policy framework to encourage $R \& D$ activity geared towards building up of in-house capabilities for product and process innovations for competing in an increasingly knowledge-based world economy. Keeping these considerations on board, a Science and Technology Policy has been announced by the Government to strengthen India's R\&D by raising its share in GNP to at least 2 percent over the medium-term (Government of India, 2003). These supply side measures would need to be buttressed with appropriate demand-side policies by adopting wellformulated competition policy and intellectual property protection measures.

\section{References}

Aggarwal, A. (2000). Deregulation, technology imports and in-house R\&D efforts: an analysis of Indian experience. Research Policy 29, 1081-93.

Aghion, P., A.Klemm, S.Bond and I.Marinescu (2004). Technology and financial structure: are innovative firms different? Journal of the European Economic Association 2, 277-88. 
Bah, R., and P.Dumontier (2001). R\&D intensity and corporate financial policy: some international evidence. Journal of Business Finance and Accounting 28, 671-92.

Cohen, W. (1995). Empirical studies of innovative activity. In P.Stoneman (Eds.) Handbook of Economics and Technological Change, Blackwell.

Czarnitzki, D., and K.Kraft (2004). Management control and innovative activity. Review of Industrial Organization 24, 1-24.

Dixon, A.J. and H.R.Seddighi (1996). An analysis of R\&D activities in North East England manufacturing firms: The results of a sample survey. Regional Studies 30, 287-94.

Erikson, R., and A. Pakes (1995). Markov-perfect industry dynamics: A framework for empirical work. Review of Economic Studies 62, 53-82.

Francis, J., and A.Smith (1995). Agency costs and innovation: some empirical evidence. Journal of Accounting and Economics 19, 383-409.

Harris, M., and A.Raviv (1991). The theory of the capital structure. Journal of Finance 46, 297-355.

Kartak, H. (1989). Imported technology and R\&D in a newly industrialising economy: the experience of Indian enterprises. Journal of Development Economics 31, 123-39.

Kartak, H. (1991). In house technological efforts, imports of technology and enterprise characteristics in a newly industrialising country: the Indian experience. Journal of International Development 3, 263-76.

Kartak, H. (1997). Developing countries' imports of technology, in house technological capabilities and efforts: an analysis of the Indian experience. Journal of Development Economics 53, 67-83.

Kumar, N. (1990). Multinational enterprises in India: industrial distribution, characteristics and performance. Routledge: London.

Kumar, N. and A.Aggarwal (2005). Liberalization, outward orientations and inhouse R\&D activity of multinational and local firms: a quantitative exploration for Indian manufacturing. Research Policy 34, 441-449.

Love, J.H., B.Ashcroft and S.Dunlop (1996). Corporate structure, ownership and the likelihood of innovation. Applied Economics 28, 737-46.

Nelson, R., and S.Winter (1982). The Evolutionary Theory of Economic Change. Cambridge and London: Harvard University Press.

Patibandla, M. (2006). Equity pattern, corporate governance and performance: A study of India's corporate sector. Journal of Economic behaviour and Organisation 59, 29-44. 